\title{
Effect of family control on corporate dividend policy of firms in Pakistan
}

\author{
Imran Yousaf ${ }^{1 *}$, Shoaib Ali ${ }^{1}$ and Arshad Hassan ${ }^{2}$
}

\author{
* Correspondence: \\ imranyousaf_12@pide.edu.pk \\ ${ }^{1}$ Faculty Member, Air University \\ School of Management, Air \\ University, Islamabad, Pakistan \\ Full list of author information is \\ available at the end of the article
}

\begin{abstract}
This study examines the impact of family control on the dividend policy of firms in Pakistan, covering the period from 2009 to 2016. It also investigates whether family control moderates the impact of firm-specific factors on the dividend policy. The GMM model for panel data estimation is used. The mean difference univariate analysis shows that family firms differ from nonfamily firms based on financial characteristics. The multivariate analysis shows that family firms pay lower dividends than nonfamily firms. Besides, firm size inversely affects the dividend policy, whereas tangibility positively affects it. Moreover, family control does not moderate the impact of all firm-specific factors on the dividend policy. Overall, family control, size, and tangibility are found to be the main determinants of the dividend policy in Pakistan.

Keywords: Family firm, Family ownership, Dividend, Minority shareholder, Expropriation, Agency conflicts
\end{abstract}

\section{Introduction}

"Corporate governance is a philosophy and mechanism that entails processes and structure which facilitate the creation of shareholder value through management of the corporate affairs in such a way that ensures the protection of the individual and collective interest of all the stakeholders" (Hasan \& Butt, 2009, p.50).

Corporate governance only modestly provides a mechanism through which outside investors can protect themselves against expropriation by insiders. It is mostly associated with the presence of agency problems, which can arise when there is a separation of control and ownership in a firm.

The agency issues may exist between managers and owners or between controlling owners and minority shareholders. Notably, owner-manager problems are fewer in family firms, but more prominent between a controlling shareholder and minority shareholders (Jensen \& Meckling, 1976). The latter case can be attributed to scenarios wherein controlling shareholders expropriate the wealth of minority shareholders. Extant research on finance also contends that family firms often expropriate the wealth of minority shareholders (De Cesari, 2012). Such firms should then pay more dividends compared with nonfamily firms to overcome agency problems and reduce agency

(c) The Author(s). 2019 Open Access This article is distributed under the terms of the Creative Commons Attribution 4.0 International License (http://creativecommons.org/licenses/by/4.0/), which permits unrestricted use, distribution, and reproduction in any medium, provided you give appropriate credit to the original author(s) and the source, provide a link to the Creative Commons license, and indicate if changes were made. 
costs. Bozec and Laurin (2008) argue that dividends can be a controlling mechanism in governance to reduce agency costs.

The Pakistan business landscape is dominated by family-owned firms. Around 59\% of nonfinancial listed firms can be classified as family-owned firms (Shahab and Attiya, 2012). These family firms are indispensable to the economic growth of Pakistan. Owners of family firms control firms through direct ownership, a pyramid structure, or a cross-holding ownership structure. These firms conventionally offer more benefit to family members (majority shareholders).

Some studies find that family firms pay less dividends than nonfamily firms do (Attig et al., 2016; Lukas, 2017; Duygun et al., 2018). Contrariwise, evidence also suggests that family firms pay higher dividends to overcome agency conflicts (Lukas, 2010). So far, there is no conclusive substantiation that resolves these contradictory findings. Our objective herein is to examine the effect of family control on the dividend policy of firms in Pakistan.

Further, previous studies focus on determining the determinants of the dividend policy of firm (Baker and Powell, 2000; Ben et al., 2006; Denis and Osobov, 2008; Ahmed and Javid, 2009; Mehta, 2012; Yousaf and Ismail, 2016; Baker et al. 2019) without segregating the family and non-family firms. Thus, this paper contributes to the strand of literature on the determinants of corporate dividend policy in two ways: first, by accounting for family control; second, by examining the moderating role of family control on 'the impact of firm-specific factors on the dividend policy'. Some investors give preference to dividend yield over capital gain while designing their portfolios. This study will be helpful for dividend demanding investors in the selection of stocks for portfolios, because this study also explores whether family firms pay more dividends or non-family firms. It will also be helpful for policymakers of the family businesses' dominant country while designing or restructuring the corporate governance code for family dominant firms to protect the rights of minority shareholders.

Our study is novel for three factors: First, scholars have rarely, if not ever, studied the stated objective in the context of Pakistan. Second, this study contributes to the corpus of literature on dividend policy in firms by focusing on an emerging economy, thus making it relevant to a large group of fast-developing countries in Asia and Africa. Third, it is particularly important to study firm policy dynamics in countries where most firms are family-run.

To examine the impact of family control on the dividend policy of firms in Pakistan, we collect sample data of 103 nonfinancial firms ranging from 2009 to 2016 and subject them to panel data analysis using the generalized method of moments (GMM). The remaining paper is structured as follows: After providing an overview of the extant literature in section 2, we explain the data, variables, and empirical methodology in section 3. In section 4, we present and discuss our findings, and then conclude in section 5 .

\section{Literature review}

Decisions on corporate dividends are the main strategic decisions of firms. In such decisions, firm characteristics are considered highly influential. These characteristics include family ownership, size, profitability, growth, leverage, tangibility, and turnover. 
This section explains the theoretical and empirical relationship between dividend policy and its determinants (including family ownership).

\section{Family ownership}

According to the agency cost theory, agency conflicts can exist between firm managers and shareholders (Jensen and Meckling, 1976). Under family ownership, the interests of shareholders and managers might align. Such mutual interests reduce agency conflicts (La Porta et al., 2000), especially given that family owners would likely monitor their managers more strictly (Anderson and Reeb, 2003). When firms distribute dividends, family owners serve as efficient monitoring mechanisms to ensure that managers do not waste free cash flow on unprofitable projects. Hence, distribution of dividends reduces agency conflicts of free cash flow between controlling and minority shareholders (Jensen, 1986). Through this strategy, firms can establish better corporate governance systems. Thus, based on the outcome model of dividends, higher dividends should be associated with better corporate governance practices.

The dividends can reduce the conflict between family and nonfamily owners. However, DeAngelo and DeAngelo (2000) argue that income and wealth preservation might reflect the preferences of family-owned firms in lieu of wealth maximization for outside shareholders through a dividend payout. Faccio et al. (2001) argue that a controlling family might expropriate the wealth of minority shareholders when its cash flow rights dwarf over minority shareholders. Gugler and Yurtoglu (2003) argue that free cash flow reduces if family firms pay higher dividends. High dividends might then decrease the tendency of family firms to expropriate wealth from minority shareholders. Moreover, De Cesari (2012) claims that family firms pay fewer dividends to preserve their cash flow for expropriation. Thus, lesser dividends indicate the possibility of wealth expropriation by family owners. Ultimately, it leads to the high agency costs (La Porta et al., 2000).

Family firms have a lower dividend payout ratio compared with state-controlled firms (Gugler et al., 2003; Duygun et al., 2018) and often use funds for own benefits. Evidently, families expropriate shareholder wealth by paying lower dividends, and minority shareholders resultingly face a loss. Villalongs and Amit (2006) maintain that conflicts arise between a large controlling shareholder and minority shareholders when the former uses firm resources for own benefits and, thus, pays fewer dividends to minority shareholders (i.e., agency problem). Li et al. (2006) find that family firms do not pay dividends smoothly and also pay fewer dividends compared with nonfamily firms (Gugler and Yuroglu, 2003); their dividends are, in fact, more volatile. Further, Jensen et al. (1992) find a negative association between insider ownership and dividend payout.

According to Baron and Kenny (1986) and Dawson (2014), testing for moderation is crucial when a contradictory relationship between the independent and dependent variable exists. That is, a relationship between two variables may be affected by a third variable. Novi and Pontoh (2018) state that a family firm with higher profitability moderates the relationship between the ownership structure and dividend. However, their results are insignificant. Similarly, they also tested for the moderating role of other firm-specific variables such as return on equity and earning per share. Saerang and Pontoh (2016) study the sample of Indonesian firms. They empirically prove that the larger the size of the family firm, the higher the dividends for shareholders. 
Size

Chang and Rhee (1990) point out that larger firms have more convenient access to capital markets at lower costs when a financing need arises. Thus, such firms can afford a higher dividend payout than smaller firms. Gaver et al. (1993), Holders et al. (1998), Fama et al. (2001), and Jones et al. (2001) similarly find an empirically positive relationship between size and dividend payout. On the other hand, Ahmed and Attiya (2009) find a negative relationship for the emerging economy of Pakistan.

\section{Profitability}

A firm pays dividends from its profits. Thus, profits indicate a firm's capacity to pay dividends. Baker et al. (1985) report that anticipated future earnings constitute the "impact determinant" of the dividend payout. Pruitt and Gitman (1991) find that past and current returns are important factors in influencing the dividend payout. The pecking order hypothesis explains this relationship between profitability and dividends. Less profitable firms would not find it optimal to pay dividends, because they consider the cost of issuing equity and debt financing. Contrariwise, highly profitable firms are better able to pay dividends. It concludes that profitability directly affects the dividend payout (Fama and French (2002).

\section{Growth}

Firms with high growth require more capital than those with lower growth because the former logically have higher investment expenditures. Such firms are expected to implement a policy of low dividend payout because they retain their profits to finance investments; they also seek to avoid the high costs of external finance (Rozeff, 1982). According to the agency theory, low-growth firms should pay higher dividends to reduce agency costs between shareholders and managers because they have lower investments expenditures and, thus, higher retained earnings. Otherwise, managers may use their firm's retained earnings or cash flow to invest in unprofitable projects if the firm is characterized by low growth opportunities. In this scenario, the best option is to distribute dividends among shareholders to reduce agency costs in lieu of wasting funds (Jensen, 1986). Hence, the agency theory predicts a negative relationship between growth and dividend payout. In the literature, both Lang et al. (1989) and Denis et al. (1994) also confirm this negative relationship.

\section{Leverage}

Based on the agency theory, Jensen (1986) argues that debt is an alternative for dividends in reducing agency conflicts. Debt repayment on higher debts reduces the cash flow available to a firm. Inevitably, the likelihood of managers investing free cash flow in unprofitable projects decreases, whereas monitoring by the capital market also increases. The agency theory also explains the negative relationship between debt and dividend payout. Kalay (1982) argues that debt covenants can force firms to limit the dividend payout. Jensen et al. (1992) and Faccio et al. (2001) empirically determine a negative relationship between leverage and dividend payout. Finding the same result, Gugler et al. (2003) argue that highly leveraged firms pay fewer dividends to shareholders because the high amount of interest and principal payments reduce firms' 
capacity to pay dividends to shareholders. Thus, highly leveraged firms pay fewer dividends to maintain their liquidity position and, thus, fulfill their current and future debt obligation. Such firms become bankrupt if a failure of debt repayment occurs (Chao et al., 2019; Chao et al., 2019) or liquidation arises. Leuz et al. (1998), Thornton (1992), and Niskanen and Niskanen (2004) suggest that debt covenants restrict dividend policy, indicating a negative relationship between leverage and dividend payout.

\section{Tangibility}

The tangibility of assets may affect the dividend policy because firms can use tangible assets as collateral against debt (Booth et al., 2001). Bradley et al. (1984) argue that firms with a higher proportion of tangible assets can fulfill their financing needs more easily and with cheaper cost through debt because they can use more tangible assets as backup or collateral against large debts. In such scenarios, there is decreased pressure on internal funds to fulfill financing needs, and firms can easily declare dividends from internal funds. Hence, these tangible assets, when taken as collateral, positively affect the dividend policy.

\section{Research methodology}

\section{Data description}

This study examines all nonfinancial listed firms on the Karachi Stock Exchange. There are 559 companies listed in Pakistan. First, we focus on 390 nonfinancial firms and exclude financial firms because the financial sector is highly controlled by regulators. Second, we exclude 287 firms due to nonavailability of data on variables for consecutive years. Third, we select 54 family and 49 nonfamily firms from the 103 remaining firms. These sample firms are chosen from 19 nonfinancial sectors in Pakistan. Table 1 reports the distribution of the full sample by industry. Our analysis uses annual data and the sample period is from 2009 to 2016. The Balance sheet analysis of stock exchange-listed firms published by State Bank of Pakistan provides us with the accounting data of firms, whereas annual financial reports of selected companies provide the family ownership-related data.

\section{Model}

The panel data framework helps us analyze the effect of family ownership on corporate strategic financial policies of firms. We use the balanced panel data of 103 crosssectional firms over 8 yrs and study a sample of 824 observations. The panel data analysis assists in investigating time-series as well as cross-sectional data simultaneously. Notably, Pindado, Requeio, and Torre (2012) and Bostanci et al., 2018) empirically prove that previous dividends affect current year dividends.

We thus use the GMM model because it is an efficient analytical method that can handle econometric problems of endogeneity and the omitted variable bias. As suggested by Roodman (2009), the lag dependent and explanatory variables are used as instruments following Arellano and Bond (1991). The functional form of our models is as follows: 
Table 1 Distribution of the full sample by industry

\begin{tabular}{llll}
\hline Industry description & Family firms & Nonfamily firms & $\begin{array}{l}\text { Percentage family } \\
\text { firms in industry }\end{array}$ \\
\hline Personal Goods (Textile) & 18 & 02 & 90.0 \\
Construction and Materials (Cement) & 04 & 05 & 44.4 \\
Electricity & 01 & 04 & 20.0 \\
Travel and Leisure & 02 & 01 & 66.6 \\
General Industrials & 04 & 01 & 80.0 \\
Automobile and Parts & 05 & 01 & 83.3 \\
Food Producers & 07 & 03 & 70.0 \\
Engineering & 01 & 01 & 50.0 \\
Forestry (Paper and Board) & 02 & 01 & 66.6 \\
Chemicals & 05 & 04 & 55.5 \\
Pharma and Bio Tech & 02 & 04 & 33.3 \\
Household Goods & 02 & 01 & 66.6 \\
Fixed Line Telecommunication & 01 & 03 & 25.0 \\
Tobacco & 00 & 02 & 0.00 \\
Industrial Transportation & 00 & 01 & 0.00 \\
Oil and Gas & 00 & 11 & 0.00 \\
Multiutilities (Gas and water) & 00 & 02 & 0.00 \\
Electronic and Electrical Goods & 00 & 01 & 0.00 \\
Software and Computer Services & 00 & 0.00 \\
Total & 54 & 01 & \\
\hline & & 01 & \\
\hline
\end{tabular}

$$
\begin{aligned}
\text { Div } i t= & \alpha_{0}+\alpha_{1}(\text { Family Ownership })_{i t}+\alpha_{2}(\text { Size })_{i t}+\alpha_{3}(\text { Profitibility })_{i t} \\
& +\alpha_{4}(\text { Growth })_{i t}+\alpha_{5}(\text { Leverage })_{i t}+\alpha_{6}(\text { Tangability })_{i t}+\alpha_{7}(\text { Turnover })_{i t}+u_{i t}
\end{aligned}
$$

There are many definitions of "family firm" in the literature. Perez-Gonzalez (2006) define one as a firm that has two or more biologically related individuals as directors, officers, or shareholders, where an individual has at least $5 \%$ ownership. Barth et al. (2005) state that if at least 33\% of the shares of a firm are owned by one person or one family, then it is a family firm.

This study defines a family firm as one that fulfills conditions (a) and (b), or only condition (c), as outlined hereafter: (a) at least two individual with a biological or connubial relationship are directors (or CEOs) of the firm; (b) individuals from a family that owns at least $20 \%$ of the shareholdings; and (c) if at least 33\% of the firms' shares are owned by one person or one family. The firm is categorized as a family firm which fulfills both (a) and (b) conditions or solely (c) Condition. All other firms are categorized as nonfamily firms.

The family dummy $(F D)$ variable is 1 for family firms and 0 otherwise. We use three dimensions to define a family firm: governance, management, and ownership. A family can influence the firm through its degree of involvement in these dimensions (Astrachan, Klein and Smyrnios, 2002). In this definition, the extent of governance is measured by directorship, management involvement by the CEO, and ownership by at least $20 \%$ of the shareholdings. 
We use two proxies of dividends: total dividends scaled by total equity as the first proxy and total dividends scaled by total assets as the second proxy. The natural logarithm of assets is a measure of the firm size. The net income scaled by total assets is a proxy for profitability and denoted by $R O A$. The market-to-book value of equity is a proxy for growth and denoted by $M / B$. The long-term debt to total assets is a proxy for firm leverage. The fixed assets scaled by total assets is a proxy for tangibility. Finally, the value of stock traded scaled by stock market capitalization is a proxy for turnover.

\section{Empirical results \\ Descriptive statistics and analysis}

\section{Summary statistics and correlation matrix}

Table 2 reports the summary statistics of the full, family, and nonfamily firms' sample. For the comparison of family and nonfamily firms, we find that: 1) The mean value of both dividend proxies is much higher for nonfamily firms. Thus, family firms pay fewer dividends in Pakistan. 2) The mean value of profitability (ROA) is much higher for family firms. 3) The market-to-book value of equity is higher for nonfamily firms, which, thus, have higher growth opportunities. 4) The leverage and tangibility of family

Table 2 Summary Statistics

\begin{tabular}{|c|c|c|c|c|c|c|c|c|}
\hline & DIV/TA & DIV/E & SIZE & $\mathrm{ROA}$ & $M / B$ & LEV & TANG & $\overline{\text { TURN }}$ \\
\hline \multicolumn{9}{|c|}{ Panel A: Summary statistics for the full sample } \\
\hline Mean & 0.073 & 0.034 & 15.563 & 9.665 & 19.017 & 0.136 & 0.476 & 0.001 \\
\hline Median & 0.012 & 0.006 & 15.559 & 6.380 & 8.447 & 0.077 & 0.474 & 0.000 \\
\hline Maximum & 3.807 & 1.964 & 19.666 & 266.050 & 151.024 & 1.073 & 0.973 & 0.027 \\
\hline Minimum & -0.070 & 0.000 & 8.536 & -46.730 & -146.26 & 0.000 & 0.001 & 0.000 \\
\hline Std. Dev. & 0.229 & 0.099 & 1.744 & 18.173 & 94.917 & 0.168 & 0.228 & 0.002 \\
\hline Obs. & 824 & 824 & 824 & 824 & 824 & 824 & 824 & 824 \\
\hline \multicolumn{9}{|c|}{ Panel B: Summary statistics for the family firm's sample } \\
\hline Mean & 0.013 & 0.028 & 14.907 & 6.712 & 6.087 & 0.151 & 0.514 & 0.000 \\
\hline Median & 0.000 & 0.000 & 14.852 & 4.260 & 5.234 & 0.102 & 0.516 & 0.000 \\
\hline Maximum & 0.484 & 1.641 & 17.852 & 266.050 & 98.113 & 0.988 & 0.965 & 0.002 \\
\hline Minimum & 0.000 & -0.070 & 8.536 & -46.730 & -653.01 & 0.000 & 0.007 & 0.000 \\
\hline Std. Dev. & 0.033 & 0.097 & 1.469 & 18.248 & 41.716 & 0.150 & 0.195 & 0.000 \\
\hline Obs. & 432 & 432 & 432 & 432 & 432 & 432 & 432 & 432 \\
\hline \multicolumn{9}{|c|}{ Panel C: Summary statistics for the non-family firm's sample } \\
\hline Mean & 0.057 & 0.124 & 16.284 & 12.913 & 33.240 & 0.120 & 0.434 & 0.001 \\
\hline Median & 0.020 & 0.051 & 16.576 & 10.760 & 14.964 & 0.037 & 0.412 & 0.000 \\
\hline Maximum & 1.964 & 3.807 & 19.666 & 63.720 & 1501.020 & 1.073 & 0.973 & 0.027 \\
\hline Minimum & 0.000 & 0.000 & 11.372 & -40.910 & -1456.26 & 0.000 & 0.001 & 0.000 \\
\hline Std. Dev. & 0.136 & 0.308 & 1.739 & 17.547 & 129.007 & 0.185 & 0.253 & 0.003 \\
\hline Obs. & 392 & 392 & 392 & 392 & 392 & 392 & 392 & 392 \\
\hline
\end{tabular}

Note: DIV/TA denotes to Dividends/Total Assets; DIV/E denotes to Dividends/Total Equity; ROA denotes to Return on Assets; M/B denotes to market-to-book value of equity; Lev denotes to leverage; Tang denotes to tangibility; and Turn denotes to Turnover 
firms are higher. 4) Finally, the standard deviation of the family firm's dividends is lesser.

The correlation matrix of different variables in Table 3 shows that leverage negatively correlates with dividends, profitability, $M / B$ ratio, and turnover. Tangibility also negatively correlates with dividends, profitability, and $M / B$ ratio. However, there is a positive relationship between dividends and profitability. This result is particularly consistent with the residual cash flows theory. Dividends are also positively correlated with firm size because larger firms have easier access to capital markets at a lower cost when financing needs arise. Hence, such firms can afford to pay higher dividends, whereas smaller firms cannot (Chang and Rhee, 1990).

\section{Mean difference univariate analysis}

Table 4 reports the results of the mean difference univariate analysis. We find that the difference between the dividends of family and nonfamily firms is statistically significant at the $1 \%$ level. Thus, family firms pay significantly smaller amounts of dividends. These results are consistent with the findings of De Cesari (2009), who states that this strategy allows family firms to preserve cash flow for expropriating the wealth of minority shareholders. Further, such firms, unlike nonfamily firms, often use their resources for own benefits (Villalonga and Amit, 2006). The size, profitability, $M / B$, leverage, and tangibility of family and nonfamily firms significantly differ. Thus, the characteristics of family firms are different from nonfamily firms in Pakistan.

Tables 5 and 6 report the regression results for the effect of family control on the dividend policy. "Dividends/total equity" is the first proxy of the dividend policy; it is a dependent variable in Table 5. "Dividends/total assets" is the proxy of the dividend policy; it is a dependent variable in Table 6.

We find that family ownership negatively affects both proxies of the dividend policy. This coefficient shows that family firms in Pakistan pay lower dividends to shareholders, which is consistent with the findings of Villalonga and Amit, 2006), Hu et al. (2007), and De Cesari (2009). That is, family firms use funds for own benefits and

Table 3 Correlation Matrix

\begin{tabular}{lllllllll}
\hline & DIV/TA & DIV/E & SIZE & ROA & M/B & LEV & TANG & TURN \\
\hline DIV/TA & 1 & & & & & & \\
DIV/E & $0.867^{* * *}$ & 1 & & & & & \\
SIZE & 0.055 & 0.056 & 1 & & & & \\
ROA & $0.303^{* * *}$ & $0.266^{* * *}$ & -0.014 & 1 & & & \\
M/B & $0.125^{* * *}$ & $0.179^{* * *}$ & -0.003 & $0.141^{* * *}$ & 1 & & \\
LEV & $-0.135^{* * *}$ & $-0.096^{* * *}$ & $0.127^{* * *}$ & $-0.324^{* * *}$ & $-0.108^{* * *}$ & 1 & \\
TANG & $-0.079^{* *}$ & $-0.090^{* * *}$ & $0.159^{* * *}$ & $-0.248^{* * *}$ & $-0.080^{* *}$ & $0.568^{* * *}$ & 1 \\
TURN & $0.188^{* * *}$ & $0.127^{* * *}$ & $0.361^{* * *}$ & $0.296^{* * *}$ & $0.064^{*}$ & -0.052 & -0.020 & 1 \\
\hline
\end{tabular}

Note: DIV/TA denotes to Dividends/Total Assets; DIV/E denotes to Dividends/Total Equity; ROA denotes to Return on Assets; M/B denotes to market-to-book value of equity; Lev denotes to leverage; Tang denotes to tangibility; and Turn denotes to Turnover

* Significance at the $10 \%$ level

** Significance at the $5 \%$ level

*** Significance at the $1 \%$ level 
Table 4 Difference of mean test for family and non-family firms

\begin{tabular}{lllll}
\hline & All & Family & Non-Family & t-statistic (2)-(3) \\
$(1)$ & $(2)$ & $(3)$ & $-6.491^{* * *}$ \\
\hline DIV/TA & 0.073 & 0.013 & 0.057 & $-6.112^{* * *}$ \\
DIV/E & 0.034 & 0.028 & 0.124 & $-11.963^{* * *}$ \\
SIZE & 15.563 & 14.907 & 16.284 & $-4.916^{* * *}$ \\
ROA & 9.665 & 6.712 & 12.913 & $-4.138^{* * *}$ \\
M/B & 19.017 & 6.087 & 33.240 & $2.694^{* * *}$ \\
LEV & 0.136 & 0.151 & 0.120 & $5.224^{* * *}$ \\
TANG & 0.476 & 0.514 & 0.434 & $-6.82^{* * *}$ \\
\hline TURN & 0.001 & 0.000 & 0.001 &
\end{tabular}

Note: This table provides the results of difference of means tests for key variables between family and nonfamily firms. The sample comprises the 54 family and 49 nonfamily firms and covers 2009 through 2016

* Significance at the $10 \%$ level

** Significance at the $5 \%$ level

*** Significance at the $1 \%$ level

families expropriate the wealth of shareholders through low a dividend payout. Ultimately, minority shareholders face a loss. Moreover, the family dummy coefficient remains negative in other models.

Firm size significantly and negatively affects both proxies of the dividend policy. That is, the tendency to pay dividends decreases as the firm size increases. Ahmed and Javid (2008) also find that firm size inversely affects the dividend policy. However, tangibility significantly and positively affects the dividend policy, in line with Pattenden and Twite (2008). Moreover, profitability, $M / B$, leverage, and turnover do not significantly affect the dividend policy. To elaborate, leverage has an insignificant but negative relationship with the dividend payout ratio, whereas higher leverage increases the risk of doing business. Thus, firms retain additional funds to safeguard themselves during adverse events.

The results clearly indicate that family ownership plays a vital role in determining the dividend policy of a firm. Our results validate the agency theory for Pakistan. That is, family firms prefer a lower dividend payout in order to preserve cash flow that they can potentially expropriate (expropriation hypothesis of the agency theory).

We also investigated whether family control moderates the impact of firm-specific factors on the dividend policy. Models 2 to 7 in Tables 5 and 6 reveal this moderating effect of the family firm with respect to firm size, profitability, $M / B$, leverage, tangibility, and turnover. We found that family control does not moderate the impact of all firmspecific factors (size, profitability, $M / B$, leverage, and tangibility) on the dividend policy. Overall, family control, size, and tangibility are the main determinants of the dividend policy in Pakistan.

\section{Conclusions and policy implications}

The objective of this study was to examine the effect of family control on the dividend policy of firms in Pakistan. It also investigated whether family control moderates the impact of firm-specific factors on the dividend policy. To this effect, a GMM model was used for panel data estimation.

We found that the mean value of the family firm's dividends is lower than that of nonfamily firms. Thus, family firms pay lesser amounts of dividends to shareholders. The univariate analysis reported a significant difference between family and nonfamily 
Table 5 Effect of family ownership on Dividend/Total Assets

\begin{tabular}{|c|c|c|c|c|c|c|c|}
\hline Variable & Model 1 & Model 2 & Model 3 & Model 4 & Model 5 & Model 6 & Model 7 \\
\hline \multirow[t]{2}{*}{$\mathrm{C}$} & 0.436 & 0.611 & 0.197 & 0.457 & 0.366 & 0.507 & 0.380 \\
\hline & $(0.046)$ & $(0.124)$ & $(0.634)$ & $(0.109)$ & $(0.277)$ & $(0.047)$ & $(0.723)$ \\
\hline \multirow[t]{2}{*}{ FD*SIZE } & & 0.024 & & & & & \\
\hline & & $(0.535)$ & & & & & \\
\hline \multirow[t]{2}{*}{$F D^{*} \mathrm{ROA}$} & & & -0.006 & & & & \\
\hline & & & $(0.44)$ & & & & \\
\hline \multirow[t]{2}{*}{$F D^{*} M / B$} & & & & 0.000 & & & \\
\hline & & & & $(0.985)$ & & & \\
\hline \multirow[t]{2}{*}{ FD*LEV } & & & & & 1.294 & & \\
\hline & & & & & $(0.678)$ & & \\
\hline \multirow[t]{2}{*}{ FD*TANG } & & & & & & 0.206 & \\
\hline & & & & & & $(0.657)$ & \\
\hline \multirow[t]{2}{*}{ FD*TURN } & & & & & & & -90.440 \\
\hline & & & & & & & $(0.944)$ \\
\hline \multirow[t]{2}{*}{ FD } & $-0.222^{* *}$ & -0.588 & -0.064 & -0.230 & -0.317 & -0.332 & -0.207 \\
\hline & $(0.024)$ & $(0.329)$ & $(0.790)$ & $(0.065)$ & $(0.225)$ & $(0.184)$ & $(0.513)$ \\
\hline \multirow[t]{2}{*}{ SIZE } & $-0.023^{* *}$ & -0.033 & -0.012 & -0.023 & -0.018 & $-0.024^{* *}$ & -0.019 \\
\hline & $(0.047)$ & 0.145 & 0.547 & 0.119 & 0.327 & 0.040 & 0.758 \\
\hline \multirow[t]{2}{*}{$\mathrm{ROA}$} & 0.001 & 0.001 & 0.004 & 0.001 & 0.001 & 0.001 & 0.001 \\
\hline & $(0.277)$ & $(0.344)$ & $(0.334)$ & $(0.445)$ & $(0.631)$ & $(0.328)$ & $(0.788)$ \\
\hline \multirow[t]{2}{*}{$M / B$} & 0.000 & 0.000 & 0.000 & 0.000 & 0.000 & 0.000 & 0.000 \\
\hline & $(0.712)$ & $(0.652)$ & $(0.974)$ & $(0.760)$ & $(0.795)$ & $(0.690)$ & $(0.821)$ \\
\hline \multirow[t]{2}{*}{ LEV } & -0.088 & -0.091 & -0.015 & -0.092 & -0.588 & -0.070 & -0.086 \\
\hline & $(0.224)$ & $(0.262)$ & $(0.896)$ & $(0.334)$ & $(0.624)$ & $(0.438)$ & $(0.515)$ \\
\hline \multirow[t]{2}{*}{ TANG } & $0.142^{* *}$ & $0.131^{*}$ & 0.070 & $0.137^{* *}$ & $0.151^{*}$ & 0.059 & 0.133 \\
\hline & $(0.027)$ & $(0.052)$ & $(0.492)$ & $(0.037)$ & $(0.076)$ & $(0.775)$ & $(0.114)$ \\
\hline \multirow[t]{2}{*}{ TURN } & 2.908 & 5.857 & -2.291 & 3.863 & 4.135 & 3.643 & 2.744 \\
\hline & $(0.363)$ & $(0.224)$ & $(0.780)$ & $(0.305)$ & $(0.334)$ & $(0.304)$ & $(0.869)$ \\
\hline$A R(1)$ & 0.000 & 0.012 & 0.058 & 0.001 & 0.009 & 0.000 & 0.001 \\
\hline$A R(2)$ & 0.433 & 0.564 & 0.765 & 0.284 & 0.691 & 0.187 & 0.884 \\
\hline Hansen(J-stat) & 0.191 & 0.216 & 0.132 & 0.109 & 0.165 & 0.221 & 0.473 \\
\hline Adj R2 & 0.581 & 0.529 & 0.344 & 0.561 & 0.485 & 0.552 & 0.503 \\
\hline
\end{tabular}

firms regarding firm characteristics such as dividends, size, profitability, growth, leverage, and tangibility. That is, family firms behave differently from nonfamily firms in Pakistan.

The multivariate analysis reported a negative relationship between family ownership and dividends. We thus infer that family firms pay lower amounts of dividends in Pakistan. Moreover, firm size inversely affects the dividend policy, whereas tangibility positively affects it. The results indicate that family control does not moderate the 
Table 6 Effect of family ownership on Dividend/Total Equity

\begin{tabular}{|c|c|c|c|c|c|c|c|}
\hline Variable & Model 1 & Model 2 & Model 3 & Model 4 & Model 5 & Model 6 & Model 7 \\
\hline \multirow[t]{2}{*}{$C$} & 0.457 & 1.228 & 0.231 & 0.522 & 0.320 & 0.652 & 0.105 \\
\hline & $(0.105)$ & $(0.320)$ & $(0.636)$ & $(0.280)$ & $(0.871)$ & $(0.322)$ & $(0.959)$ \\
\hline \multirow[t]{2}{*}{ FD*SIZE } & & 0.040 & & & & & \\
\hline & & $(0.651)$ & & & & & \\
\hline \multirow[t]{2}{*}{$F D^{*} \mathrm{ROA}$} & & & -0.014 & & & & \\
\hline & & & $(0.235)$ & & & & \\
\hline \multirow[t]{2}{*}{$F D^{*} M / B$} & & & & -0.002 & & & \\
\hline & & & & $(0.625)$ & & & \\
\hline \multirow[t]{2}{*}{ FD*LEV } & & & & & 3.183 & & \\
\hline & & & & & $(0.714)$ & & \\
\hline \multirow[t]{2}{*}{ FD*TANG } & & & & & & -1.114 & \\
\hline & & & & & & $(0.571)$ & \\
\hline \multirow[t]{2}{*}{ FD*TURN } & & & & & & & -723.940 \\
\hline & & & & & & & $(0.714)$ \\
\hline \multirow[t]{2}{*}{ FD } & $-0.230^{* *}$ & -1.098 & -0.053 & -0.309 & -0.538 & 0.057 & -0.221 \\
\hline & $(0.06)$ & $(0.46)$ & $(0.85)$ & $(0.14)$ & $(0.30)$ & $(0.94)$ & $(0.74)$ \\
\hline \multirow[t]{2}{*}{ SIZE } & $-0.023^{*}$ & -0.065 & -0.014 & -0.025 & -0.013 & -0.042 & 0.000 \\
\hline & $(0.10)$ & $(0.35)$ & $(0.55)$ & $(0.33)$ & $(0.90)$ & $(0.33)$ & (014) \\
\hline \multirow[t]{2}{*}{$\mathrm{ROA}$} & 0.001 & 0.001 & 0.009 & 0.001 & 0.001 & 0.001 & 0.003 \\
\hline & $(0.42)$ & $(0.64)$ & $(0.17)$ & $(0.59)$ & $(0.85)$ & $(0.57)$ & $(0.62)$ \\
\hline \multirow[t]{2}{*}{$M / B$} & 0.000 & 0.000 & 0.001 & 0.001 & 0.003 & 0.000 & 0.001 \\
\hline & $(0.738)$ & $(0.954)$ & $(0.576)$ & $(0.458)$ & $(0.728)$ & $(0.887)$ & $(0.679)$ \\
\hline \multirow[t]{2}{*}{ LEV } & -0.094 & -0.138 & 0.065 & -0.138 & -1.279 & -0.233 & $-0.029^{* *}$ \\
\hline & $(0.249)$ & $(0.516)$ & $(0.712)$ & $(0.441)$ & $(0.684)$ & $(0.512)$ & $(0.923)$ \\
\hline \multirow[t]{2}{*}{ TANG } & $0.137^{* *}$ & 0.263 & 0.077 & 0.193 & 0.225 & 0.735 & 0.187 \\
\hline & $(0.042)$ & $(0.169)$ & $(0.582)$ & $(0.099) *$ & $(0.398)$ & $(0.458)$ & (0.398) \\
\hline \multirow[t]{2}{*}{ TURN } & 3.869 & 4.502 & -13.543 & 1.028 & 2.067 & -2.548 & -8.053 \\
\hline & $(0.300)$ & $(0.674)$ & $(0.343)$ & $(0.891)$ & $(0.856)$ & $(0.820)$ & $(0.755)$ \\
\hline$A R(1)$ & 0.023 & 0.000 & 0.011 & 0.001 & 0.005 & 0.089 & 0.025 \\
\hline $\operatorname{AR}(2)$ & 0.355 & 0.632 & 0.183 & 0.754 & 0.583 & 0.118 & 0.196 \\
\hline Hansen(J-Stat) & 0.228 & 0.187 & 0.159 & 0.193 & 0.438 & 0.122 & 0.172 \\
\hline adj. R2 & 0.563 & 0.331 & 0.395 & 0.329 & 0.398 & 0.419 & 0.342 \\
\hline
\end{tabular}

This table reports fixed effects multivariate regression results of family ownership on dividends per share of the firms. The sample comprises the 107 family and nonfamily firms and covers 2009 through 2016. Parentheses represents the P-value

* Significance at the $10 \%$ level

** Significance at the $5 \%$ level

*** Significance at the $1 \%$ level

impact of all firm-specific factors (size, profitability, $M / B$, leverage, and tangibility) on the dividend policy.

Overall, family control, size, and tangibility were found to be the main determinants of the dividend policy of firms in Pakistan. This study could help lawmakers in establishing policies that protect the rights of minority shareholders and help firms in devising internal governance mechanisms that reduce the misuse or waste of free cash flow for own benefits. The lawmakers can also protect the right of minority shareholders by restricting the companies the companies (especially family firms) to pay minimum 
threshold level of dividend payout to shareholders. Moreover, it also suggests that minority shareholders should invest in non-family firms in Pakistan, if they prefer dividend yield over the capital gain in stocks.

This study provides useful implications for investors and policymakers in emerging markets. However, we should acknowledge the few limitations of this study. First, this study only focuses on non-financial financial firms, instead of focusing on both financial and non-financial firms to examine the impact of family control on dividend policy in Pakistan. Second, this study only focuses on the impact of family control on dividend policy, but it does not estimate the impact of family control on financing and investing decisions of the firms. Third, this study considers the all family firms as one group, but some family groups may be different from other family groups in dividend paying behavior. For future research, dividend policy of different big family groups can also be studied to provide in-depth information to investors.

Acknowledgements

We gratefully acknowledge Mr. Kashif Javed (Manager, Brokerage House, AKD Securities Ltd) for his valuable suggestions and discussions.

\section{Authors' contributions}

All authors contributed equally. All authors read and approved the final manuscript.

Funding

There are no funding sources.

Availability of data and materials

The datasets will be provided on request.

Ethics approval and consent to participate

Not applicable.

\section{Consent for publication}

Not applicable.

\section{Competing interests}

The authors declare that they have no competing interests.

Thank you for your consideration. I look forward to hearing from you.

Sincerely,

Imran Yousaf.

Air University, Islamabad.

imranyousaf_12@pide.edu.pk

\section{Author details}

${ }^{1}$ Faculty Member, Air University School of Management, Air University, Islamabad, Pakistan. ${ }^{2}$ Professor/ Dean of Management and Social Sciences Department, Capital University of Science and Technology, Islamabad, Pakistan.

Received: 4 October 2018 Accepted: 30 October 2019

Published online: 11 November 2019

References

Ahmed H, Attiya J (2009) Dynamics and determinants of dividend policy in Pakistan: evidence from Karachi stock exchange non-financial firms. Int J Finance Econ 25:1-171

Anderson RC, Reeb DM (2003) Founding-family ownership and firm performance: evidence from the S\&P 500. J Financ 58(3): $1301-1327$

Arellano M, Bond S (1991) Some tests of specification for panel data: Monte Carlo evidence and an application to employment equations. Rev Econ Stud 58(2):277-297

Baker HK, Dewasiri NJ, Yatiwelle Koralalage WB, Azeez AA (2019) Dividend policy determinants of Sri Lankan firms: a triangulation approach. Manag Financ 45(1):2-20

Baker HK, Farrelly GE, Edelman RB (1985) A survey of management views on

Baker HK, Powell GE (2000) Determinants of corporate dividend policy: a survey of NYSE firms. Financial Pract Educ 10:29-40

Baron RM, Kenny DA (1986) The moderator-mediator variable distinction in social psychological research: conceptual, strategic, and statistical considerations. J Pers Soc Psychol 51(6):1173

Booth L, Aivazian V, Demirguc-Kunt A, Maksimovic V (2001) Capital structures in developing countries. J Financ 56(1):87-130 Bostanci F, Kadioglu E, Sayilgan G (2018) Determinants of dividend payout decisions: a dynamic panel data analysis of Turkish stock market. Int J Financial Stud 6(4):93 
Bozec Y, Laurin C (2008) Large shareholder entrenchment and performance: empirical evidence from Canada. J Bus Financ Acc 35(1-2):25-49

Bradley M, Jarrell GA, Kim E (1984) On the existence of an optimal capital structure: theory and evidence. J Financ 39(3):857-878

Chang RP, Rhee SG (1990) The impact of personal taxes on corporate dividend policy and capital structure decisions. Financ Manag:21-31

Chao, X., Kou, G., Peng, Y., \& Alsaadi, F. E. (2019). Behavior monitoring methods for trade-based money laundering integrating macro and micro prudential regulation: a case from China. Technological and Economic Development of Economy, 1-16. https://doi.org/10.3846/tede.2019.9383

Dawson JF (2014) Moderation in management research: what, why, when, and how. J Bus Psychol 29(1):1-19

De Cesari A (2012) Expropriation of minority shareholders and payout policy. Br Account Rev 44(4):207-220

DeAngelo H, DeAngelo L (2000) Controlling stockholders and the disciplinary role of corporate payout policy: a study of the times Mirror company. J Financ Econ 56(2):153-207

Denis DJ, Denis DK, Sarin A (1994) The information content of dividend changes: cash flow signaling, overinvestment, and dividend clienteles. J Financ Quant Anal 29(04):567-587

Denis DJ, Osobov I (2008) Why do firms pay dividends? International evidence on the determinants of dividend policy. J Financ Econ 89(1):62-82

Faccio M, Lang LH, Young L (2001) Dividends and expropriation. Am Econ Rev:54-78

Fama EF, French KR (2002) Testing trade-off and pecking order predictions about dividends and debt. Rev Financ Stud 15(1):1-33

Gaver JJ, Gaver KM (1993) Additional evidence on the association between the investment opportunity set and corporate financing, dividend, and compensation policies. J Account Econ 16(1):125-160

Gugler K, Yurtoglu BB (2003) Corporate governance and dividend pay-out policy in Germany. Eur Econ Rev 47(4):731-758

Hasan A, Butt SA (2009) Impact of ownership structure and corporate governance on capital structure of Pakistani listed companies. Int J Business Management 4(2):50-57

Hu, Y., Wang, D., \& Zhang, S. (2007). Founding family ownership, management, and payout policy. working paper, Temple University, University of Nebraska-Lincoln, and Marshall University

Jensen GR, Solberg DP, Zorn TS (1992) Simultaneous determination of insider ownership, debt, and dividend policies. J Financ Quant Anal 27(02):247-263

Jensen MC (1986) Agency costs of free cash flow, corporate finance, and takeovers. Am Econ Rev:323-329

Kalay A (1982) Stockholder-bondholder conflict and dividend constraints. J Financ Econ 10(2):211-233

La Porta R, Lopez-de-Silanes F, Shleifer A, Vishny RW (2000) Agency problems and dividend policies around the world. J Financ 55(1):1-33

Lang LH, Litzenberger RH (1989) Dividend announcements: cash flow signalling vs. free cash flow hypothesis? J Financ Econ 24(1):181-191

Leuz C, Deller D, Stubenrath M (1998) An international comparison of accounting-based payout restrictions in the United States, United Kingdom and Germany. Account Bus Res 28(2):111-129

Li D, Moshirian F, Pham PK, Zein J (2006) When financial institutions are large shareholders: the role of macro corporate governance environments. J Financ 61(6):2975-3007

Mehta A (2012) An empirical analysis of determinants of dividend policy-evidence from the UAE companies. Global Rev Account Finance 3(1):18-31

Niskanen J, Niskanen M (2004) Covenants and small business lending: the Finnish case. Small Bus Econ 23(2):137-149

Novi SB, Pontoh W (2018) The moderating effect of shareholder features on dividend disbursement: evidence from Indonesia. Invest Management Financial Innovations 15(3):343

Pattenden K, Twite G (2008) Taxes and dividend policy under alternative tax regimes. J Corp Finan 14(1):1-16

Pruitt SW, Gitman LW (1991) The interactions between the investment, financing, and dividend decisions of major US firms. Financ Rev 26(33):409-430

Roodman D (2009) How to do xtabond2: an introduction to difference and system GMM in Stata. Stata J 9(1):86-136

Rozeff MS (1982) Growth, beta and agency costs as determinants of dividend payout ratios. J Financ Res 5(3):249-259

Saerang, D. P. E., \& Pontoh, W. (2016). The role of ownership on behavior of dividend payers. J Life Econ, 3(4), 59-68. https:// doi.org/10.15637/jlecon.156

Thornton DB (1992) Costs of accounting to lenders: Canadian evidence. Account Bus Res 22(87):261-273

Villalonga B, Amit R (2006) How do family ownership, control and management affect firm value? J Financ Econ 80(2): $385-417$

Yusof Y, Ismail S (2016) Determinants of dividend policy of public listed companies in Malaysia. Rev Int Business Strat 26(1):88-99

\section{Publisher's Note}

Springer Nature remains neutral with regard to jurisdictional claims in published maps and institutional affiliations. 